
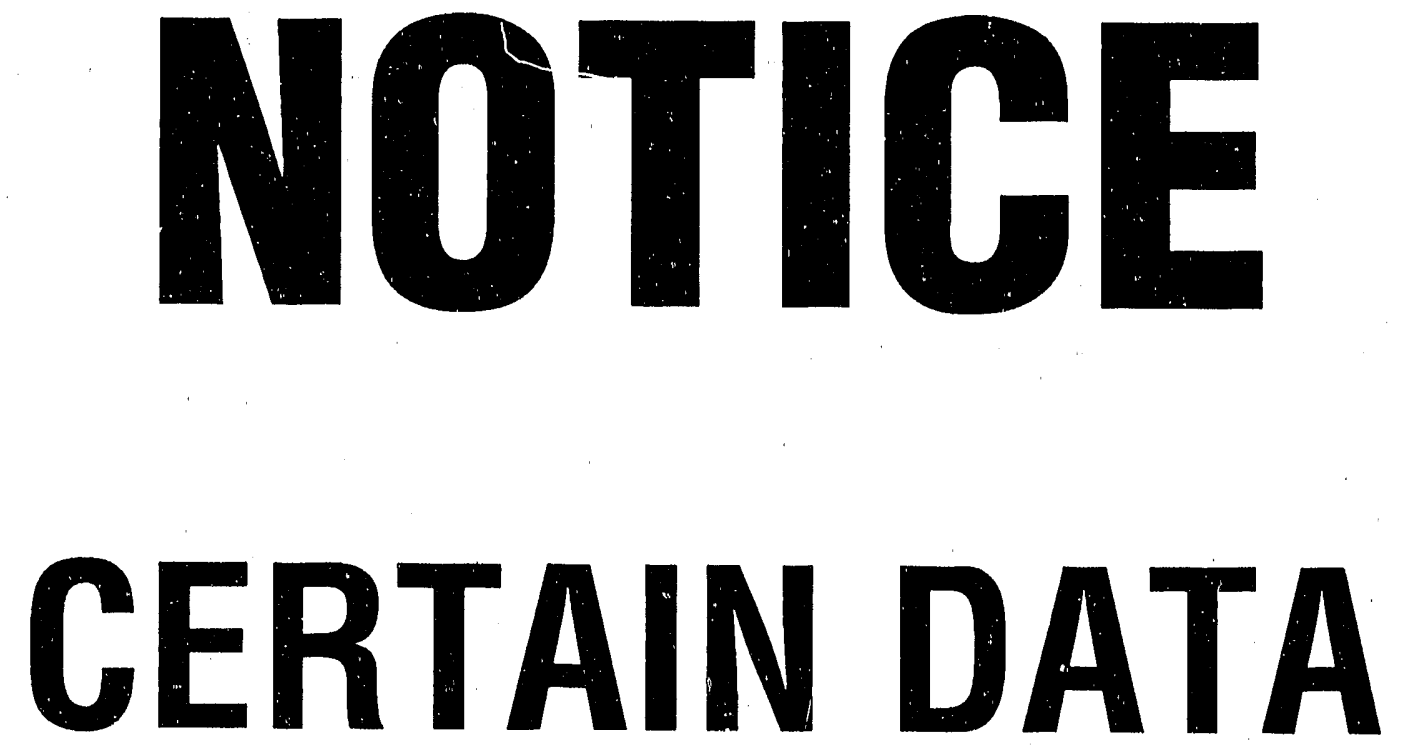

CONTAINED IN THIS
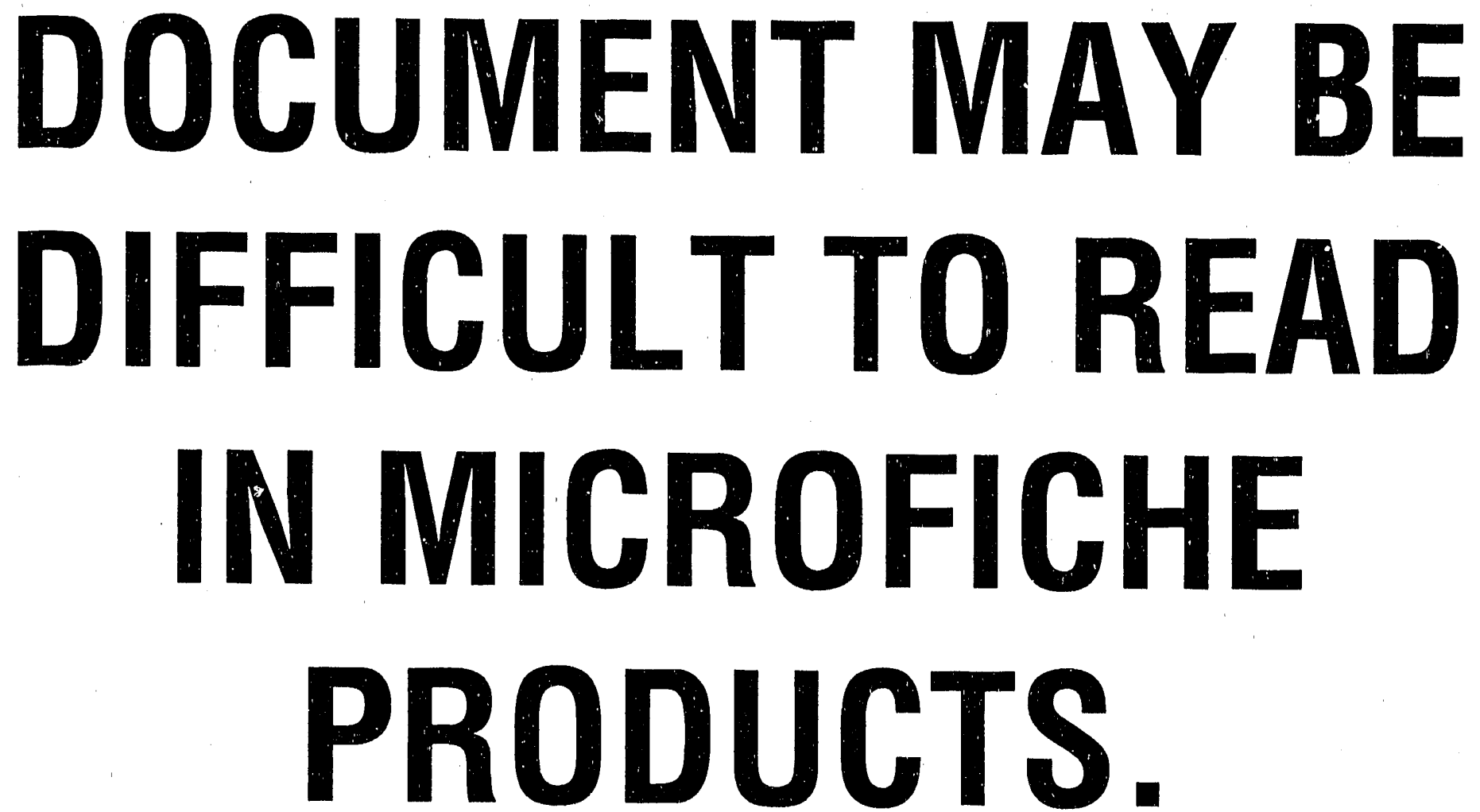


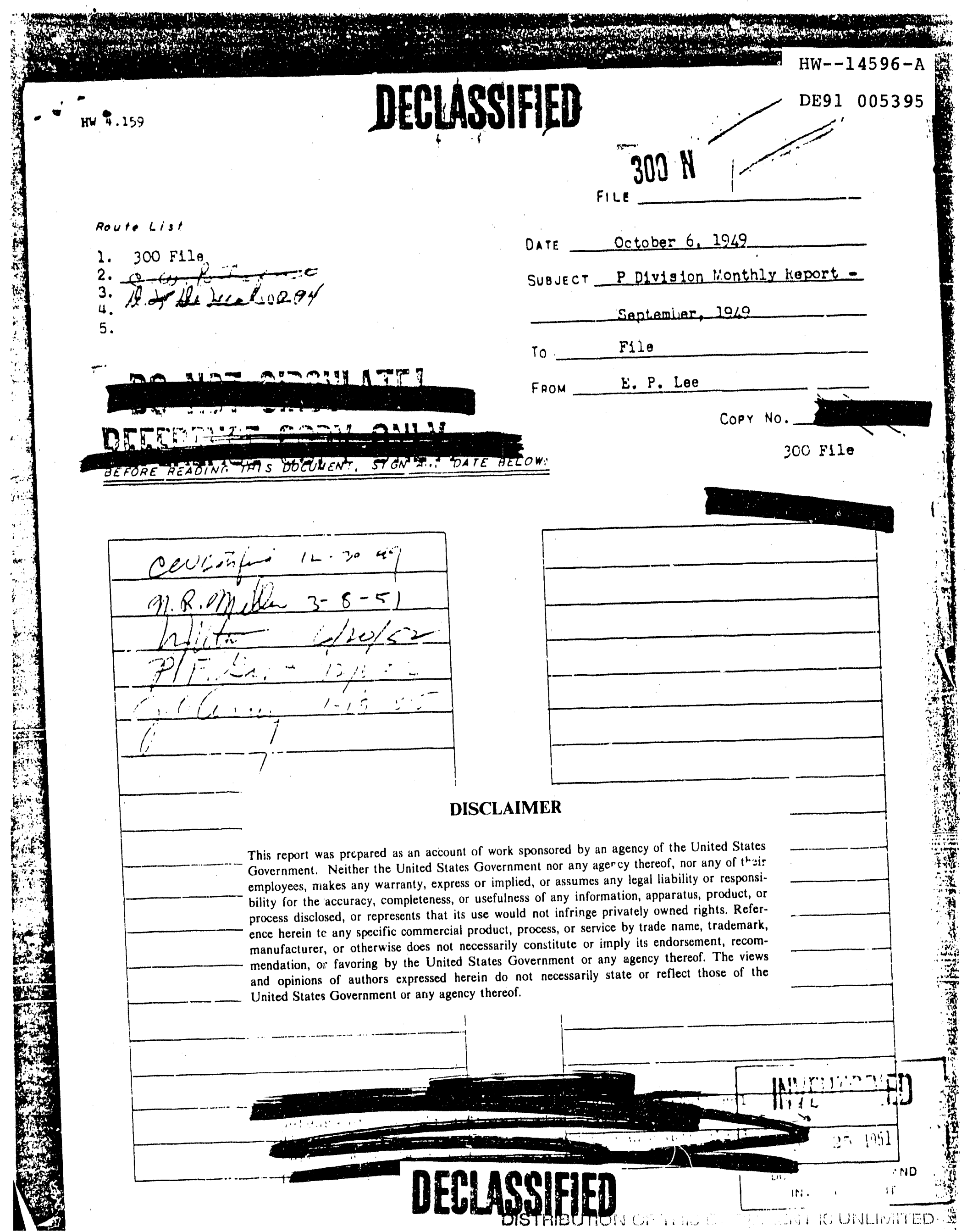


Due to film deterioration, portions of this document may be illegible.
DECLASSIEIED

vuulos \#1 thru \#17 - lionthily beport

\#1: - IP Loo - Jill ilarran

419 - ill rindshoimer

$\#: 00$ - PE Lon:

:2? - ip :..ccuo

tizi: - KO Lenann

$\# 23$ - lib Heinann

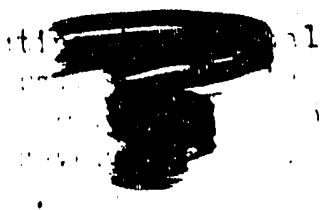

ri:4 - Ab Greninger

$-7 i<5-3,0 \mathrm{Fi}=0$

(126-7x):110

Octcber 6, 1949

\section{P D.VISION:}

SEPTE:IBEF, 1949

I. GETESiL

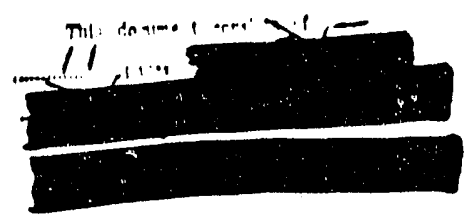

The $B$ and $F$ piles operated at 275 MN and the $D$ pile at 305 in throughout the month except for cutages listed under Area ictivities.

A total of 60.22 tons of metal, at an average concentration of $396 \mathrm{~min} / \mathrm{t}$, $\mathrm{n}$, was discharged from the piles during the month.

The 105-H Building was accepted fiom the Construction Division on September 28 with certaln exseptions noted under the Operating Experience section of this report. At month end $P$ Division operatine personel are making preparations for activation of the $H$ pile.

On Septerter 28 the oporation of the 300 Area oxide burn- PM Eack $11-26: 90$ ine process wes reduced from a two shift to a one shift five day operation. This change in schedule was possible as a lesult of morking off the backlog of urnntum oxide.

The shipment of 200 tons of cenned slugs to Bullding 105-LR for storige was completed on September 9 and the shipment of 250 tons of canned slugs io Bulding 105-4 for the initial loading charg" was completed on September 26.

Cisssification Lancelled (Chango to

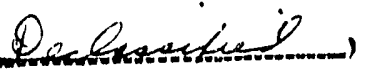




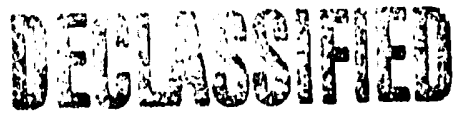

P Division

One operator and ono steno-typiot terminated voluntarily.

One opirator returned from leavo of absence and one

operator ;was rehirod to fill a vacancy in the 300 Arsa.

In addition, ono ateno-typist was transferred from the

Congtruction forcos and one was hired to f1ll vacanclos

in the 100 Aross.

Two Shift Supervisorg, B. E. Dalton and J. D. Darby, wera removed from the rolls of the 300 Area, offective September 1. T. M. Hall, Shift Supervigor, roturned from leave of absence. $\pi$. N. Koop and C. E. Jones mare added to the $P$ Division rolls as Supervisors in Training; theso men were transferred from the Technical and Hualth Instrument Divisions, respotively.

Twenty-five operators and lliree supervicurs mere transferred to 100-H Arua from the othor 100 Areas. This compietes the transier or operating personnel in preperation for tha start-up of $H$ plle.

III. AREA ACTIVITIDS

\section{PIIE SUMRARY}

Timo Operatod ( $p$ )

Operating Efficioncy

* Powar Levol (XN)

* Inlet Vlater Temperature ( $\left.{ }^{\circ} \mathrm{C}\right)$

* Outlet Plater Temperature (liaximum

${ }^{\circ}$., 10 tubes, 0.240 " Zone)

Number of Scrans

Number of Purges

Helium Consumption (cu, ft.)

Metal Discharged (tons)

Inhours Gained (this month)

* Inhours Poisoned

* Inhours in Rods

\begin{tabular}{ccc} 
PILE B & PILED & PILEF \\
\hline 91.5 & 85.6 & 91.5 \\
89.7 & 83.4 & 89.9 \\
275 & 305 & 275 \\
18.0 & 18.4 & 18.1 \\
& & \\
54.3 & 52.5 & 55.2 \\
1 & 1 & 1 \\
1 & 1 & 0 \\
19503 & $65427 * *$ & 23348 \\
17.52 & 26.31 & 16.39 \\
5 & 1 & 6 \\
511 & 525 & 539 \\
65 & 71 & 55
\end{tabular}

* Rontr. end rigures.

* Inclutes consumption of $15,000 \mathrm{cu}$. rt. at DF pile.

\section{PILE QUILDIIV}

Qutage Ereakdonn

Schoduled

Date of Outage Metal Digcharged Maintenance Unscreduled
Leneth of

Cutage (hicurs)

$$
\begin{aligned}
& 9-1-49 \\
& 9-8-49 \\
& 9-10-49 \\
& 9-10-49 \\
& 9-10-49
\end{aligned}
$$

b

F

5

$\begin{array}{rr} & 21.3 \\ & 36.5 \\ 3 & 19.3 * \\ 5 & .7 * \\ F & .6\end{array}$


P Division

Four rear and three front Van Stone rlanges protected by sacrificial magnesium gaskets were Inspected and all wore found to be in good condition.

105-168-P (Replacemsnt of Pile Helium atmosphere with $\mathrm{CO}_{2}$ ) The $\mathrm{CO}_{2}$ concentration $\mathrm{Aa} 3$ maintalned at $6 \mathrm{C} / \mathrm{s}$ in $B$ and $F$ plies and $40 \%$ in D pile throughout the month.

105-214-P (S111ca Feed Reduction - Supplenent B) No sodium sillcate vas added to the process water at the plles during the month. Pressure drop film formation and decomposition appears to have reached an equilibrlum vaiue in the central tubes of $B$ and $F$ piles. In the $D$ pile, however, a purge ias necessary at the end of the month because of a sudden unexplained increase in iifin formation rate.

During the purge of the 105-D pile (9-28-49) a screen on the solids injection system split, permitting large particles of solids to enter the process water system. This rosulted in severe plugging of the screens on $C$ and $D$ riser and the subsequent charging of thoso scrocne necessitated approximately $15 \frac{\mathrm{t}}{2}$ hours of additional outage time. After startup, there was evidence of ccno scroan plugging on five tubes and the unit was shut down for an additional 2.3 hours to change these screens.

The orlifices in the inlot end of the process tubes were charged to the next larger size on 13 tubes in $B$ pile, 43 tuhes in $D$ pile and 21 tubes in $F$ pile during tho month to ruliove high exit water temperaturs conditions following startur).

During the month, srgmental discharge of four tubes ivas attonptod. Iwo tubes at $\bar{B}$ pile vere discharged without incident. The tape? wolild not entar one tube at $D$ pile and it could not be discharged; the other tube was procossud without incident.

A total of 55.12 tons of Group V (alpha rollod, triplo dipped, complotely transformed) matarial was discharged during tho month at an average concentration of $406 \mathrm{~km} / \mathrm{H} / \mathrm{t}$, wh thout incident.

Four procoss tubes were replacod during the month (chamae).s $0574-B, 3469-D, 1659-D$ and $1758-D$ ) and the tubc was removed from channcl $4280-F$ for corrosion studies.

The 105-H area was accuptod from the Construction Division on September 28 , 19.49 with certain exceptions. The work requirud to complete tho unaccoptod 1tems will be performed by the Manufacturing Division Mechanical Divisions porsonnol on mork order

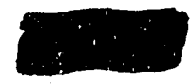




\section{P DIvioion}

Quthorization from the Construction Division. Included in the work yet to bo completed aro theso ma for 1 tomas

1. Bulanco bulleing ventllation syotom.

2. Make unit flow ticot.

3. Complcto installation and tusting of gino analysis instrumontztion.

4. Roplaco inlot and outlet ceps.

5. Complote 1nstaliation of B tost holo insert..

6. Chango all crose hoador scroons and ldentify hoadors and tubes.

7. Corplote installation and testine of pannolit gaugos.

\section{Mochanical Exporienco}

At morth und all hor 1 zontsl and vorticril onfoty rodis ar: in gatiefretory operating condition with the oxception of \#32-F which is tied out duo to exccssive binds ne.

Work of an unusunl nature porformod on the gafoty rods during the month includod the following:

1. No. 31-B rod was ruplaced with a stalnless stool rod and guido.

2. Replecement of uletrical londs on $\# 16-3$ anci \#17-B rods contirued during the montn.

3. The pneumat1c testing of all virtical sofoty rod thimbles was complutod durine the month. Thimblos \#18-F and \#31-F arore roplnced :nd \#26-F romins to bo roplacerl. Ho. 23-F, roportod lonking (sco Fill-14338-A), was rotested and found to bo satisfactory.

4. The tip of H5-D rod was ruplacod on Scptembur 15 aftor a meter leak mas obsorvod in the tip.

Tho afr inlot duct to the rear face of $D$ pile was found to be blockod with wator during thre septumbir 15 outnge. Thr duct nas pumpod dry and the drnin clonnod. At month und, the condition of the duct appones a tisfactory.

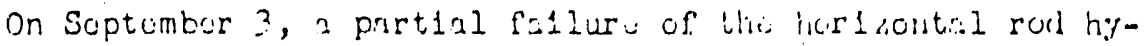

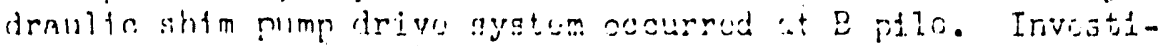
gation ruvealed that uxcussives lurknpe of oil nt 49 drive motor had resulted in the trensfer of considurable oll from tho shim pump scimpo to the nccurnulstor pump sumps via the dratn 11nc. Tho shim pump surpis irepe rofllled and the motor is schadulud for overhnul to privent ruoccurrance of the condition. Tho emorgency accumulator system was not affectod by this troublo.

Tho inspuction of the rront inds of 35 tubos in $D$ pile rovonled corrogion produci doposition in guveral tubes but no evidenco of pltting in any axcupt $179 \%_{*}-D$. This tubs was pittod the the 
P Division

Van Stone flange and also in the tube downstream of the flange. Further evaluation of this problem is being made by the Technical Divisions.

The t1e-in of the 107-Dif efrluenti line at 1904-D was completed during the ronth.

\section{Dile Area Development}

A removable shield was developed at $F$ pilo during the nonth for use while cutting vertical safoty rod thimbles. Personnel exposure during thimble replacement wrs roduced $50 \%$ by use of this devico.

A revision of the Control foom $\pi x G$ (Beckman) clrcuits was made in all plles during the month. The rovigion provides a saparate fuse for the heater and electrometer circults and is expected to minimize ocrams caused by fuse fallure in the hostco ciscuid.

\section{Proces Control Activities}

During the month, forty-ona procedure rovisions and twelve log sheet rovistions were procussod in preparation for the activation of the $\mathrm{H}$ pllo. In addition tive group undertook now rospons1bilities in connection with projest and cost engineoring, began a training program for two new supervisors, and continued the routine production accounting and schoduling work, suggostion processing and dovolopment investigation.

\section{Gas Procnssing Building}

Oporations in these bulldings ivere normal during the montli. sixteen thousand pounds of liquid $\mathrm{CO}_{2}$ " oro unloadud into storage at $210 . .14$ on Soptumber 2.2.

\section{Spectal Hazards}

Slight decreases in the intensity of the bunm at the top far odges of $D$ and $F$ pilos acru ruported durine the month.

\section{AREA - METAL FABR ICh' ION}

Eroduction Stat1stics

Production for the month of Septumber ins ns follows:

$\begin{array}{ll}\text { Billete produced } & 20 \text { Tons } \\ \text { Rodo Wichinod } & 72 \text { Tons } \\ \text { Baro Pieces lachince } & 53 \text { T'ons } \\ \text { Accoptable Piecos Cunned } & 69 \text { Tons }\end{array}$

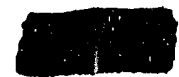


P Disision

Melt Plant

The casting yiulds woro as follons:

\begin{tabular}{|c|c|c|c|}
\hline & August & Soptomber & $\begin{array}{l}\text { T'o Dato } \\
10,49\end{array}$ \\
\hline $\begin{array}{l}\text { B1llet } \\
\text { Solid Metal }\end{array}$ & $\begin{array}{l}66.0 \\
84.6\end{array}$ & $\begin{array}{l}68.8 \\
84.4\end{array}$ & $\begin{array}{l}68.1 \\
95.6\end{array}$ \\
\hline
\end{tabular}

An Incroaso in billet ylold was obtalned by procossine current

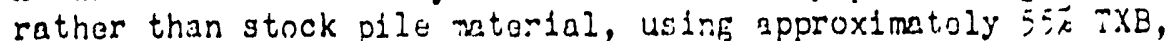
31\% U1A, and $14, \%$ romelt por furnace charge. In add1t1=n, nbout $90 \%$ of the TXB charged ras processed rrem pleklod chips.

The now Cochran Bly sem 7 sg usod satisfactorlly for t1llet cropping throughout the nonth.

\section{Machining}

Hachining ylelds nore sts follows:

\begin{tabular}{|c|c|c|}
\hline August & Staptember & $\begin{array}{l}\text { Io Dato } \\
19 ; 9\end{array}$ \\
\hline 71.3 & 72.6 & 69.9 \\
\hline
\end{tabular}

The higher yield this month resulted from a reduction in turning scrap. Rod diameters ranged from 1.408" to $1.460^{n}$, with an avirage of approximately 1.42.5 . The amount of sclid scrap on sone of tho lots machincd wes high becauso a number of rods were ulfptical and had deep surface grooves and volds.

A total of 21 thermocouple slues inas machined on Septembsr 14. Thege slugs aro to br used for 100 area test purposes.

\section{Chip liecovery}

The Chip Recovery yitid wis is follo:.

\begin{tabular}{|c|c|c|}
\hline Aürust. & Soptombry & $\begin{array}{l}\therefore=D r_{1} t .6 \\
\geq ? ! ?\end{array}$ \\
\hline 90.5 & 92.1 & jo. \\
\hline
\end{tabular}

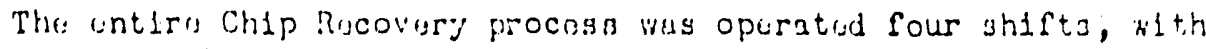

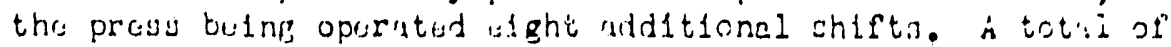
20,257 pounds of TXB was produced, of which 92.7 percent xrs processod from picklud chips.

7

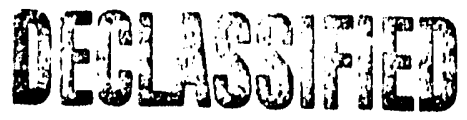

$$
\text { int }
$$


P Division

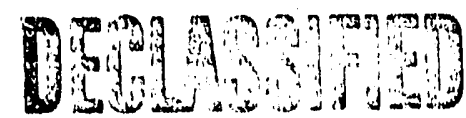

\section{Ox1do Burning}

The material burned was as follows:

\begin{tabular}{|c|c|c|}
\hline Aupust & Septombor & $\begin{array}{l}\text { To Dato } \\
1949\end{array}$ \\
\hline 41,831 & 95,776 & 230,920 \\
\hline
\end{tabular}

Oxido burning, was contin'ad on a tiro-inift flvo-day wook schodulo unt11 Septomber 26, at wich timo operction was decruesed to a one-shift flvo-day weok. The backlog of oxldas for burning had boon oufficlently roducod, ga a rasult of using tho outgasing purnaco for ronsting, to isarent this chango in schoduling.

\section{Cannfre Uporation}

The canning yleld was as followa:

\begin{tabular}{|c|c|c|}
\hline August & Septombor & $\begin{array}{l}\text { To } D a \neq 0 \\
19,49\end{array}$ \\
\hline 91.6 & 91.1 & .91 .2 \\
\hline
\end{tabular}

Canning, rojects, by cause, wers

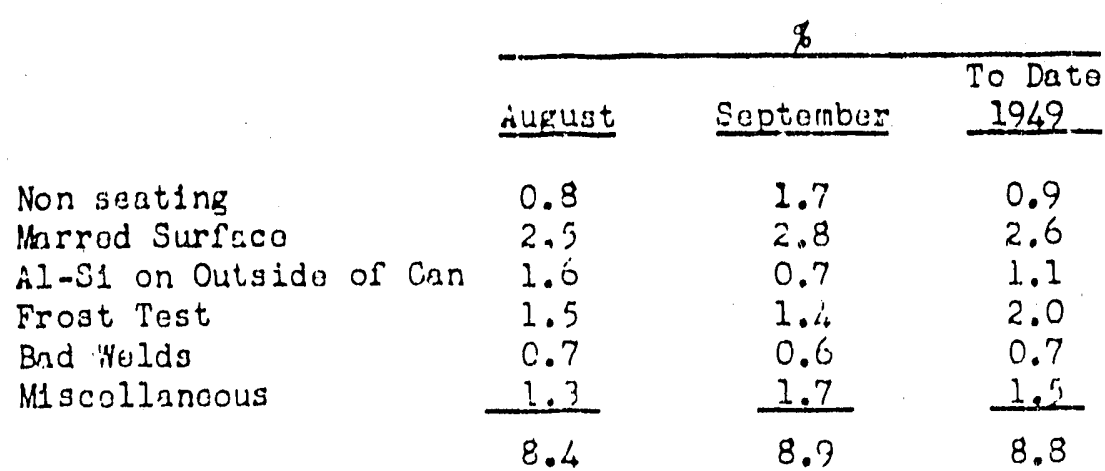

The canning yield was slightly lower this month than in wugust. Defoctive thermocouplos in tho canning betis on two occosions rosulted in nn shnermn! numbor of piicus luint rojectod ror non-sonting. a mechanicil fnilurs of an eloctric holst causud 108 pieces to be apillud in a degreneer and rajoctud for marred surfaco. t.l-Si rojects wert roduced spprocizbly through improvod crimpinp tochniquis.

ill pieces canned on sugugt 1 and 2 vihich havo boen held for investigation (sou Document Hii-14338-is) wero ro-etched and thoso having caps containing uxcosive copper, as indicated

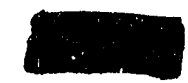




\section{P Division}

by off color, wore rejected. Only seven plecos wore refuctod and the remainder was ruleasod as accoptablo.

th total of 686 slugs was cannod by tho land dip process in conformance with Production Test No. 313-109-M, (Heat Treating Uranium by Electrical Induction). One hundred sixtoon slugs fabricatod from deplatod uranilum more canned by tho load dip procoss undor Production Tos: No. 31.3-110-M, (Load D1p Canning of $U-238)$.

Tho following special request plucus woro cannod:

$\circ$

Buguost No.

$P-10-4$

ORNL
Contants

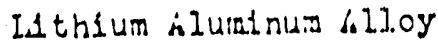
hlpho Follod Urantum

(Pb Dip Canned)
No, of Plocos

312

80

In acidtion 3070 land slugs and 1,2 urantum rocoptaclo slugg were cannod.

\section{Slug Recovory}

\begin{tabular}{lcc} 
& \multicolumn{2}{c}{ \& Recovorod } \\
\cline { 2 - 3 } & Soptember & \multicolumn{1}{c}{ To Rato } \\
\cline { 2 - 3 } & & \\
Z Slugs & 95.3 & 88.8 \\
X Slugs & 4.3 & 9.2 \\
Rujocts & $\frac{0.4}{100.0}$ & $\frac{2.0}{100.0}$
\end{tabular}

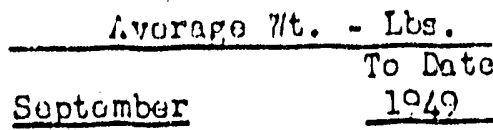

Inspection and Testing

iutoclavo rofecto nure ue follows:

$$
\begin{array}{lll}
\text { udedit } & \text { Soptamber } & \begin{array}{l}
\text { To Dnte } \\
1949
\end{array} \\
0.08 / \mathrm{M} & 0.08 / \mathrm{M} & .06 / \mathrm{M}
\end{array}
$$

Throe complets "utoclave fullures cocired in soptumber.

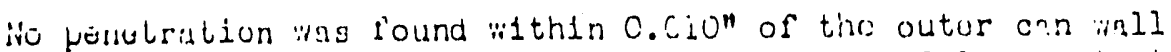
on nny of the pioces tosted during the month. Only one toet sample showed ponotrition at $0.015 \%$ "。

The "as reculved" quallty of cans, enps, and slowves inupucted was as follows: 


\section{DECLASSIFIED}

P Division

\begin{tabular}{|c|c|c|c|}
\hline & \multicolumn{3}{|c|}{ \% Usable } \\
\hline & Auguat & Soptambor & $\begin{array}{l}\text { To Dato } \\
19.49 \\
\end{array}$ \\
\hline $\begin{array}{l}\text { Aluminum Cans } \\
\text { Aluminum Caps } \\
\text { Steol Slucven }\end{array}$ & $\begin{array}{c}94.9 \\
86.4 \\
*\end{array}$ & $\begin{array}{l}93.8 \\
90.5 \\
84.4\end{array}$ & $\begin{array}{l}94.5 \\
93.4 \\
86.4\end{array}$ \\
\hline
\end{tabular}

* No new slafives nura inspected.

A total of 3480 aluminum cans recelvisd from Scoville Manufasturing Company wes inspected and $97.7 \%$ wero acceptabla.

Materind Hundling

An additional 21,402 cunnud slugg wer's transferred to 100-DK for storagu and 128,502 cannicd slueg wero shippod to $100-11$ for Inltinl loading.

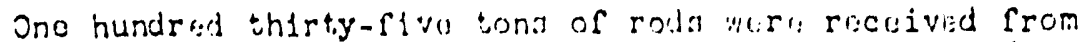
Simonda Snw and Ste:ul Cunpany and 21 tons of oxides (KD-6) were shlpped to linllinckrodt Chumical Works.

\section{Test Pilo}

The tost plle was operated on 1 one-shift five-day wook schudula. - Ninetiy-four ticsts wore run on cannod slugs, 29 on blllet ef,es, 384 on graphite bars, and the folloning on special ivork requusts:

\begin{tabular}{|c|c|c|}
\hline Request No. & No. & of icgts \\
\hline $97 \& 98$ & $\begin{array}{l}\text { To test the effuctioness oi boric } \\
\text { acid type } P \text { column to be us ad as a } \\
\text { temporary } P \text { column in tho } 105 \text { plies. }\end{array}$ & 15 \\
\hline 99 & To make boron calibrition of 305 pile. & 4 \\
\hline 100 & To determine purity of Sh-6.5 picons. & 24 \\
\hline 101 & To collow, instrument. & 1 \\
\hline $10 ?$ & To callbriates Inetrument. & 1 \\
\hline $10 ?$ & To Les: $\ddot{r}-10-\dot{A}$ slugs. & $1 ?$ \\
\hline$i \%$ & $\begin{array}{l}\text { Gtandnrdize incirument.: for obtialn- } \\
\text { ing date on Pr-2a5-105. }\end{array}$ & 1. \\
\hline 105 & $\begin{array}{l}\text { jort P-ll-d olug's to be lied in the } 105 \\
\text { riles. }\end{array}$ & 96 \\
\hline
\end{tabular}

\section{Spucinl Hiszirds}

No unusual condltions develuped during the month. 


\section{P Division}

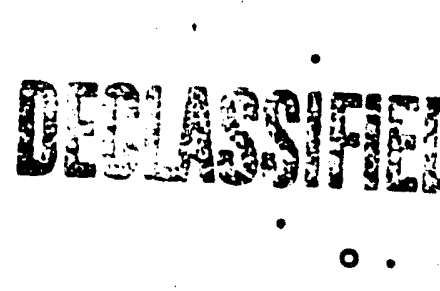

yevelopment

Test runs were completed this month to determin' the l'ensibility of using the outgrsoing furnace to burn oxides. Hesulis in-

- dicated that this furnacu whs mora cificlont and has about twice the sapacity of the ex!sting propinu burner. It. Has converted for the routine burning of oxides on Suptember $t$. An estimatod manpoiver sevings of about $33,000.00$ will result from the usn of the olectric furnace to reduce the current backlor of oxidis, and an annual manpovir savings thereafter of about $\$ 3500.03$ bnsed on present production, rit..s.

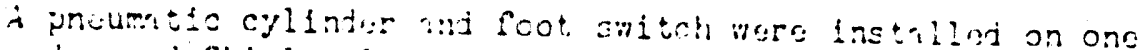
Lodge and Shipley lis this to actliate the gtert!ni sad stopping rechantsm. The regulti have teon viry satlatectory and cho; a tise anvines of 116 Scr facinp crnored 3luss. It 13 plannid to make this inst3llation on the two remanire lithes, irich icuuire manuel optration of the clutich and trikt..

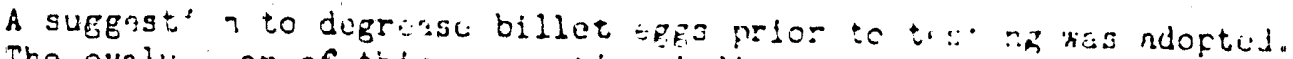

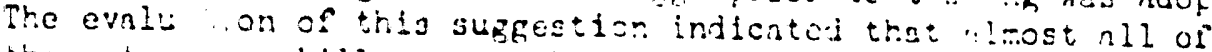
the retes - on billo: agga risuled from centen-in ison that co-id

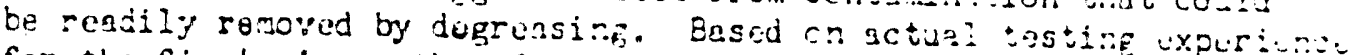

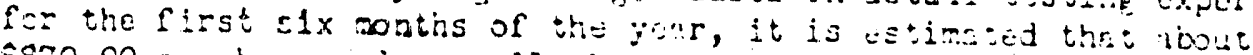
6870.00 can be saved annully bj degrunging billet eges and thus elininating the cost of retosting in most c:s:s. arofiltion

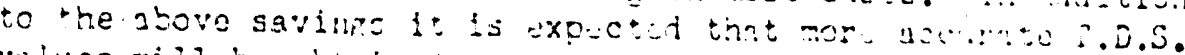

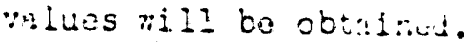



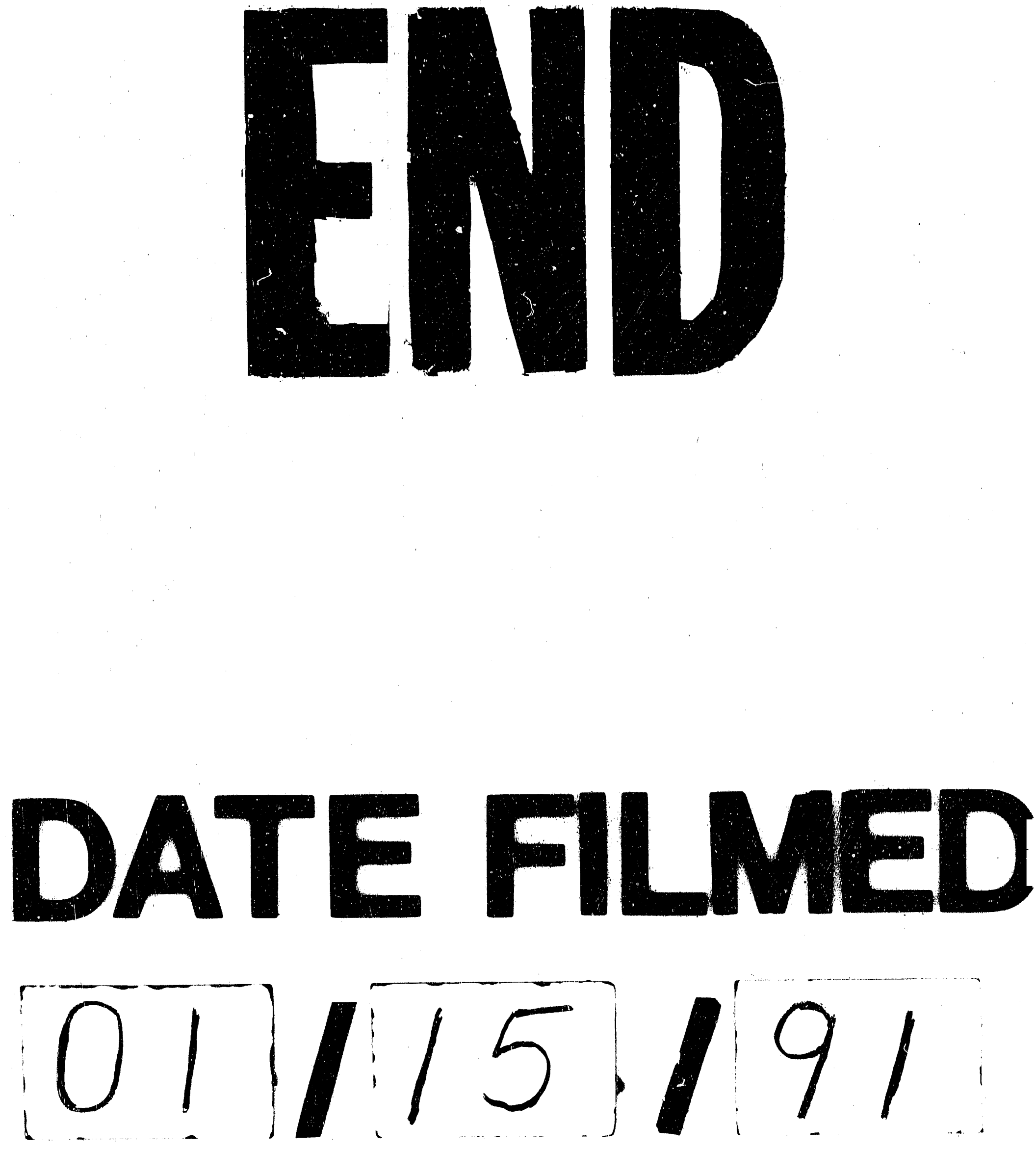


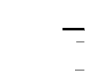

